\title{
Discussion on Reinforcing the Party 's Discipline Construction in New Era
}

\author{
Wen Wei \\ College of Science and Art, Xiangtan University, Hunan, China, 411105
}

Keywords: party discipline, party rules, party building, traditional styling elements, application

\begin{abstract}
Discipline construction is one of the six major party buildings explicitly proposed by General Secretary Xi Jinping in the report of the 19th National Congress. Strengthening discipline building is an excellent tradition in which the party strengthens itself. It is an important magic weapon for the party to continuously victoriously win it. It is also a distinctive feature and a significant advantage that Chinese Communist Party is distinguished from other political parties. The current party is leading the people to carry out the great struggle with many new historical features and facing unprecedented challenges and difficulties. In order to smoothly accomplish the goals of "two hundred and 100 years" and the Chinese dream of rejuvenating the great nation as schedule, it wins the Chinese characteristics of the new era. For the great victory of socialism, it is necessary to strengthen the party's discipline construction. It safeguards the authority of the Party Central Committee, ensures the unity and unification of the Party, and always maintains the party's advanced nature and purity.
\end{abstract}

\section{Strictly obey the party's discipline and rules to strengthen party discipline}

Party discipline is a code of conduct that the party organizations at all levels and all party members must abide by. To give full play to the role of party discipline, we must first of all strictly discipline the party's discipline and rules.

\subsection{Strict discipline of the party as the fine tradition of the Chinese Communist Party}

No rules, no standards. Strict discipline is a distinctive feature of the Chinese Communist Party. When the party can develop from a small party with only 50 or more party members at the time, its founding is the ruling party with 89 million party members today. It is by strict discipline. Since its inception, the party has emphasized strict discipline. In July 1921, the first major party passed the "Outline of the Party". It is initially formulated the party's discipline and highlighted the party's secrecy discipline. In July 1922, the "Party Constitution" special column "Discipline" passed by the party's two major legislatures. It put forward the requirements of political discipline, organization discipline and confidential discipline. In the spring of 1928, Mao Zedong first proposed three major disciplines, followed by six notices. After several amendments and supplements, Mao Zedong formed the iron law of the People's Army - eight notices of the three major disciplines and it was fixed by order in 1947. In March 1949, at the 2nd Plenary Session of the Seventh Central Committee of the Party, the Central Party Central Committee set six pre-rules of "going to Beijing for the examination of the capital". As a result, the critical juncture that the new-democratic revolution is about to win the victory of the entire country. The party's centripetal force is strengthened. Cohesion and combat are effective.

\subsection{Strict discipline and rules of the party are the most fundamental}

If the party strictly rules the party's management of the party, it must strictly observe the party's discipline and rules. The rules of the party include: first, the party constitution is the general constitution that the entire party must abide by and also the general principle [1]. Second, party discipline is rigid and political discipline is the rigid constraint that the entire party must abide by in its political, political, political, and political actions. Third, state laws are the rules that party members and cadres must abide by. The law is formulated by the party leading the people and the entire party must be exemplary. Fourthly, the excellent traditions and work practices formed by the 
party in long-term practice have been proved by practice. They are well-established and effective and require the entire party's long-term adherence to and conscious compliance with [1]. "Discipline is a written rule. Some unwritten rules are unwritten disciplines. Discipline is a rigid one. Some rules that are not expressly included in discipline are self-discipline." "The rules of the party" include the party constitution, party discipline, state law, fine traditions and work practices have a greater extension than "party discipline". And discipline is a rigid rule. Good traditions and work practices are unwritten and relatively flexible rules. They also need to be observed.

Among the discipline and rules of the party, Xi Jinping particularly emphasized the "political discipline" that is related to the party's line and stance. The "political rules" are critical to the rise and fall of the cause. He pointed out that "among all the party's disciplines and rules, the first is the political discipline and political rules. Political discipline is the most important, fundamental and crucial discipline. The party's political discipline is the basis of abiding [2]. Implementing the party's political discipline and political rules have always been the party's political superiority. The "Resolution on Organizational Issues" passed by the party's top five in 1927 stipulated that "party discipline is very important. And the political discipline should be emphasized"[3]. The "Decision of the CPC Central Committee on Party Reorganization" in 1983 stipulated that each party organization and every party member must adhere to the four cardinal principles and adhere to the party's principle since the Third Plenary Session of the 11th Central Government. This is the party's political discipline. In 1987, the Central Commission for Discipline Inspection pointed out that, in the solemn and solemn party discipline. The first one is to strictly implement the party's political discipline. "Political discipline ... is the fundamental guarantee for the unity and unification of the party. [2]"

\subsection{The discipline and rules of the party must be strictly followed without any exception}

Marx once pointed out: "We must absolutely maintain the party's discipline now or else nothing will be done [4]." Lenin once emphasized that "the unconditional centralization and strict discipline of the proletariat is one of the basic conditions for defeating the bourgeoisie. [5] " To strictly abide by and enforce party discipline rules is an important guarantee for the continuous progress of the communist party from victory to victory. In October 1937, regarding the disposal of Huang Ke Gong, the Red Army general, Mao Zedong replied to Yanjingtian's letter in Yan'an in October 1937. "The Communist Party and the Red Army cannot impose more stringent disciplines on civilians than their own party members and Red Army members." 1 "Mao Zedong especially emphasized that" no disruptive discipline exists in the People's Liberation Army. [6] " In December 1951, regarding Liu Qingshan and Zhang Zishan, Mao Zedong said:" it is only possible to save 20 and two one hundred, two thousand, twenty thousand guilty of cadres with varying degrees of error. "Xi Jinping pointed out:" the implementation of the party's discipline cannot be any ambiguity.

\section{To strengthen the practical value of the party's discipline construction}

Strengthening discipline construction in the party is an important measure for strengthening party. It is proposed by the party in accordance with the requirements of the new situation and new mission. It has a strong reality and pertinence. And it points the way for party members and cadres to firmly establish the awareness of discipline and rules.

\subsection{Strengthening the party's discipline construction is an urgent need of the party's self-construction under the new situation}

The founding of the party over the past 90 years has proved that Party discipline is the lifeline of the party, and it cannot be slackened in the event of a complete and solemn ruling party. The key to a comprehensive and strict control of the party in an all-round manner lies in governance. The key lies in strictness. Since the 18th CPC National Congress, the party Central Committee with Comrade Xi Jinping at the core has been strengthening the party building in an all-round manner. Resolutely it has been changing the soft and loose conditions of party and party administration, and has achieved remarkable results in the overall strict control of the party. However, the inner-party 
political life in some places is still not solemn. Various forms of liberalism still exist, which harms the party's core leadership and affects the party's centralized and unified leadership. Therefore, strengthening party discipline construction is an urgent need and an important measure for further improving the party's political ecology, purifying the social environment and consolidating the party's ruling position under the new situation. We must strictly abide by the discipline rules of the party and strictly enforce the rules and regulations of the party, so that the majority of party members and cadres cannot violate the rules of the party's discipline. The discipline and rules of the party are the insurmountable bottom line for all party members and party organizations at all levels. The mined areas that cannot be touched are the code of conduct that all party members must abide by. If they are conscientious and disciplined, Party members and cadres have a good command of the rules and have a fair and honest attitude.

\subsection{Strengthening the Party's Discipline Construction is the Objective Requirement of Seizing the Great Victory of Socialism with Chinese Characteristics in the New Era}

At present, the party faces "the four major dangers" and "the four major tests." If the party will complete the new mission of the new era, we must strengthen the party's discipline construction. Only by strengthening the party's discipline construction we can push forward the deepening of the reform in an all-round way. Only by strengthening the party's discipline construction the law-based governance can be promoted in an all-round way. Only by strengthening the party's discipline construction the party's construction can be truly strengthened and improved, so that the leadership of the party can be truly strengthened and improved. The party must be built into a leading Marxist ruling party that has always walked in the forefront of the times. The people wholeheartedly support and have the courage to revolutionize itself and withstand all kinds of tests and trials. Only by strengthening party discipline construction can we fully build a well-to-do society, build a prosperous, strong, democratic, civilized and harmonious socialist powerhouse.

\section{Taking effective measures to strengthen party discipline construction}

To build the Chinese Communist Party into the most powerful political party in the world, we must strictly observe the Party's discipline. The key to strictly discipline the Party is implementation. To truly implement the party with strict discipline, we give full play to the role of discipline, education, prevention, warning and punishment. We improve the party's cohesion and combat effectiveness and we must adopt effective measures.

\subsection{Adhere to the combination of strict implementation and implementation}

To ensure that party discipline achieves effective results, we must not only strictly discipline the party's discipline, but also strictly implement it according to the specific conditions. Party members must be conscientiously abiding by the party discipline so as to ensure that all party members firmly and correctly establish their political beliefs, political positions and political orientation. They also require that the party discipline must keep pace with the times and continue to meet the new requirements and requirements of new tasks and tasks while requiring the party to make. Put forward the correct political task and political line.

\subsection{The implementation of the main responsibility of party committees and the supervision of Commission for Discipline Inspection combined}

No clear responsibility, no responsibility, no accountability, strict discipline is tantamount to negotiating on paper. It is meaningless. Therefore, it is not only necessary to clarify the main responsibilities of party committees, but also it need to strengthen the supervision responsibility of discipline inspection commission. Meanwhile, it needs to make the two complement each other. As far as the main responsibility of the party committees is concerned, the party secretary as the first responsible person should set an example for the party loyalty. It is dare to pick the heavy burden, honest and diligent. It should be strict with the party discipline as a matter of importance and it should be responsible. Meanwhile, it should lead the party organization. The party discipline 
implemented in the party in charge of party governance gives a comprehensive grasp of the party members. The party members and cadres and the moral character are ability to work hard, honest and diligent and so on. As a result, it can manage all the party members and party organizations. In terms of the responsibility of discipline inspection commission, the discipline inspection organs at all levels should step up supervision and discipline and increase their accountability. Adhere to the responsibility must ask, accountability it must be strict.

\subsection{Adhere to the party's political construction, ideological and institutional integration}

Paying attention to the party's political construction, the combination of ideological and institutional construction are valuable experiences that the CPC has to strengthen its own construction and maintain its advanced nature. The party's political construction is the fundamental construction of the party and determines the direction and effect of the party's construction. Clearly speaking, politics is the fundamental requirement of our party as a Marxist political party. Only by strengthening the political construction of the party, the party's political orientation can be correct. The political principles can be determined and the political line can be correct. The will of the entire party can be uniformed, the power of the whole party solidified and the party can work together to achieve its program and objectives. Ideological building is the precondition and foundation of system construction.

\subsection{Strengthen the theoretical education and strengthen the combination of accountability}

The development of discipline must be based on a higher theoretical level. Therefore, in the process of strict discipline and party discipline, we must strengthen theoretical education and enhance the theoretical accomplishments of Party members and cadres. We should overcome blindness and raise their consciousness. To strengthen the awareness of discipline and rules, we must step up education in the basic principles of Marxism. It is enable the majority of party members to truly grasp the Marxist standpoint, methods and points of view. This will enhance the political immunity against all temptations.

\section{References}

[1] "Xi Jinping series important speech reading", Beijing Learning Press, People's Publishing House 2016 edition, the $119,119$.

[2] Selected Documents of Important Literature since the 18th National Congress of the Communist Party of China (on), Beijing Central Literature Publishing House 2014 Edition, pp. 764, 131-132, 132, 43.

[3] "Central Committee of the CPC Central Committee," the first three volumes (1927), Beijing Central Party School Press 1989

[4] "Complete Works of Marx and Engels," Volume 29, People's Publishing House, 1972 edition, p. 413.

[5] "Lenin feature collection - On the proletarian party," People's Publishing House, 2009 edition, 244, 245 pages.

[6] "Mao Zedong Collection" Volume 2, Beijing People's Publishing House, 1993 edition, the first 39 pages. 